\title{
PENGARUH KEPEMIMPINAN REPALA SEKOLAH, SUPERVISI, DAN PARTISIPASI KOMITE SEKOLAH TERHADAP KINERJA SEKOLAH
}

\author{
Oleb: \\ Bambang Susanto
}

\begin{abstract}
Abstrak
Penelitian ini bertujuan untuk mengungkapkan pengaruh kualitas kepemimpinan kepala sekolah, supervisi pengajaran, dan komite sekolah terhadap kinerja sekolah.

Populasi penelitian adalah guru dan kepala sekolah pada empat puluh sekolah dasar di Kecamatan Grogol, Kabupaten Sukoharjo, sebanyak 240 orang. Sampel penelitian sebanyak 150 orang guru pada dua puluh lima sekolah dasar yang diambil dengan teknik cluster random sampling.

Hasil penelitian menunjukkan bahwa: (1) kualitas kepemimpinan kepala sekolah tergolong sedang, aktivitas supervisi tergolong sedang, dan partisipasi komite sekolah juga tergolong sedang; (2) ada korelasi positif dan signifikan antara kualitas kepemimpinan kepala sekolah dengan kinerja sekolah, demikian juga antara supervisi pengajaran dan partisipasi komite sekolah dengan kinerja sekolah; (3) hasil analisis regresi ganda menunjukkan adanya korelasi ganda yang signifikan $(R=0,656$; $\mathrm{P}=<0,05)$ kualitas kepemimpinan kepala sekolah, aktivitas supervisi pengajaran, dan partisipasi komite sekolah terhadap kinerja sekolah.
\end{abstract}

Kata kunci: kepemimpinan, supervisi, komite sekolab, kinerja sekolab. 


\section{Pendahuluan}

Dalam memasuki era global, kompetisi menjadi bagian yang tidak terpisahkan dalam kehidupan. Agar mampu bersaing dengan baik, diperlukan modal yang kuat dan strategi yang memadai. Modal dana sangat diperlukan. Akan tetapi, dengan dana yang cukup apakah ada jaminan bahwa kemenangan dapat diraih. Tentu kita tidak bisa memberikan jawab-an pasti. Pertanyaan selanjutnya, modal apa yang sangat diperlukan untuk dapat bertahan, bahkan mampu meraih kemenangan dalam persaingan global? Tidak lain adalah sumber daya manusia yang berkualitas.

Sekarang persoalannya adalah apa yang dimaksud dengan sumber daya manusia yang berkualitas? Siapa yang bertanggung jawab? Bagaimana-kah cara menciptakannya? Tentu saja pertanyaan-pertanyaan ini tidaklah mudah untuk dijawab. Salah satu lembaga yang bertanggung jawab menciptakan sumber daya manusia yang berkualitas adalah institusi pendidikan.

Sumber daya manusia yang berkualitas, dalam konteks pendidikan adalah mutu output pendidikan yang mampu memenuhi harapan masyara-kat, mampu menjawab tantangan perubahan, bahkan mampu memelopori terjadinya perubahan. Lembaga pendidikan dituntut untuk menghasilkan lulusan yang mampu beradaptasi dengan lingkungan global, mampu me-nyiasati perubahan, mampu berbuat sesuatu yang sesuai dengan tuntutan perubahan, atau mampu berpikir, bersikap, dan berperilaku sesuai dengan tantangan zaman. Dengan demikian, tugas dan fungsi pendidikan pada era globalisasi adalah mencipkan sumber daya manusia yang berkualitas sehing-ga memiliki daya saing yang tinggi. Untuk itu, perlu adanya kesungguhan dalam pemikiran dan penelitian yang mendalam agar dapat dirumuskan konsep serta strategi pendidikan yang tepat.

Dewasa ini di Indonesia mutu output pendidikan masih relatif rendah. Berbagai upaya telah dilakukan guna meningkatkan mutu pendidikan. Namun demikian, hingga saat ini hasilnya masih belum meng-gembirakan. Hal ini terjadi karena berbagai hal, antara lain:

1. Penyelenggaraan pendidikan nasional dilakukan secara birokratik-sentralistik sehingga menempatkan sekolah sebagai penyelenggara pendidikan sangat 
bergantung pada keputusan birokrasi yang tidak menutup kemungkinan mempunyai jalur yang sangat panjang, dan kadang-kadang kebijakan yang dikeluarkan tidak sesuai dengan kondisi sekolah setempat (Depdiknas, 2002: 2).

2. Peran serta warga masyarakat, khususnya orang tua siswa dan tokoh-tokoh masyarakat dalam penyelenggaraan pendidikan masih sangat minim.

3. Pengelolaan pendidikan di lingkungan sekolah sebagian besar dilakukan dengan kurang transparan, kurang akuntabel, dan tidak berkesinam-bungan.

4. Belum ada standar mutu lulusan untuk setiap jenjang, jenis, dan satuan pendidikan yang berlaku secara nasional ataupun internasional.

5. Belum ada persamaan persepsi antara pemerintah, sekolah, dan masyarakat tentang tanggung jawab pendidikan sehingga kesadaran, pemikiran, sikap, tekad, dan prilaku di antara mereka belum ada kesamaan. Tentu saja hal ini akan mempersulit langkah pengelola sekolah dalam meningkatkan mutu output sekolah.

Meskipun demikian upaya meningkatkan mutu output pendidikan terus dilakukan. Salah satu upaya yang dilakukan adalah mengimplemen-tasikan manajemen berbasis sekolah, yaitu model manajemen yang memberikan otonomi (kewenangan) yang lebih besar kepada sekolah, dan mendorong partisipasi secara langsung warga sekolah (guru, siswa, kepala sekolah, karyawan) dan warga masyarakat (orang tua siswa, tokoh masyarakat, ilmuwan, pengusaha, dan sebagainya) agar dapat melaksanakan pendidikan sesuai dengan kebutuhan, perkembangn zaman, karakteristik lingkungan dan tuntutan global (Mulyasa, 2003: 31)

Mengelola sekolah dengan model ini berlandaskan konsep bahwa sekolah sebagai suatu sistem. Sekolah sebagai suatu sistem terdapat tiga komponen pokok yang saling berkaitan yaitu: input - proses - output. Input adalah segala sesuatu yang diperlukan untuk berlangsungnya proses pendidikan, khususnya proses belajar mengajar. Input digolongkan menjadi dua yaitu yang diolah dan pengolahnya. Input yang diolah adalah siswa dan input pengolah meliputi visi, misi, tujuan, sasaran, kurikulum, tenaga kependidikan, sarana, prasarana, regulasi sekolah, organisasi sekolah, administrasi sekolah, budaya sekolah, dan peran masyarakat dalam mendu-kung sekolah. Adapun proses adalah kejadian 
berubahnya sesuatu menjadi sesuatu yang lain. Dalam pendidikan, komponen proses meliputi mana-jemen, kepemimpinan, dan utamanya proses belajar mengajar. Output adalah hasil belajar yang merefleksikan seberapa efektif proses belajar mengajar diselenggarakan. Output pendidikan ini dapat berupa prestasi akademik dan nonakademik. Prestasi akademik ditunjukan oleh seberapa besar kemampuan akademik yang dapat diukur melalui evaluasi hasil belajar serta karya ilmiah lainnya. Adapun prestasi nonakademik diukur dari perilaku siswa yang dipresentasikan melalui aspek seperti kedisiplinan, tata krama, kebersihah, keindahan, kenyamanan, keamanan, dan sebagainya (Slamet, 2003: 2-6) .

Ketiga komponen tersebut, saling terkait dan saling berpengaruh. $\mathrm{Hal}$ ini berarti bahwa output sekolah yang baik ditentukan oleh kualitas proses persekolahan yang baik pula. Proses dalam konteks ini yaitu bagaimana kepemimpinan sekolah, bagaimana manajemen sekolah, dan bagaimana proses belajar mengajarnya. Efektivitas dan efisiensi suatu proses sangat bergantung dari kualitas inputnya. Dengan demikian, input yang berkualitas berpengaruh terhadap terjadinya proses yang berkualitas; dan proses yang berkualitas memungkinkan terciptanya output yang berkualitas pula.

Model manajemen berbasis sekolah merupakan model manajemen yang relatif baru, di dalam implementasinya diperlukan: (a) kepemimpinan yang kuat, (b) partisipasi warga sekolah dan warga masyarakat yang tinggi, (c) pengelolaan tenaga kependidikan yang efektif, (d) proses belajar mengajar yang efektif, (e) keterbukaan dan kemauan untuk berubah, (f) responsif dan antisipatif, (g) akuntabilitas, (h) teannvork yang cerdas, kompak, dinamis, dan sebagainya (Depdiknas, 2002: 14-18). Model manajemen ini tentu menuntut adanya perubahan wacana, pemikiran, sikap, tekat, dan tindakan nyata bagi. semua pihak yang berkepentingan terhadap pendidikan. Kondisi yang demikian ini sudah barang tentu akan timbul berbagai persoalan. Agar persoalan yang mungkin timbul dapat dieliminasi dan dapat diatasi, perlu adanya penelitian yang seksama sehingga ditemukan jenis hambatan serta faktor penyebabnya ${ }^{-}$ yang pada gilirannya dapat dirumuskan jalan keluarnya.

Kaitannya dengan persoalan tersebut, peneliti telah melakukan prasurvei pada tingkat sekolah dasar di wilayah Cabang Dinas Pendidikan Kecamatan 
Grogol Kabupaten Sukoharjo. Prasurvei ini diperoleh fakta bahwa: (a) model manajemen berbasis sekolah telah diimplementasikan di setiap sekolah dasar yang berada di wilayah tersebut, (b) komite sekolah telah terbentuk di setiap sekolah sebagai pengganti BP3. Namun demikian, ada fenomena lain yang menarik, antara lain: (a) terjadi penurunan jumlah murid dari tahun ke tahun, khususnya di sekolah-sekolah yang berlokasi di perbatasan antara Grogol dan Surakarta, (b) prestasi sekolah dari tahun ketahun belum ada perbaikan yang berarti, (c) peran serta warga sekolah dan warga masyarakat dalam penyelenggaraan pendidikan pada umumnya masih bersifat rutinitas.

Dengan melihat fenomena tersebut, timbulah suatu pertanyaan antara lain: (a) bagaimana kepemimpinan kepala sekolahnya, (b) bagaimana partisipasi masyarakatnya, dan (c) bagaimana sikap dan perilaku semua pihak yang seharusnya bertanggung jawab terhadap pendidikan. Dengan fenomena dan latar belakang pemikiran yang demikian, perlu dilakukan penelitian dengan memfokuskan pada permasalahan yang dianggap penting, yaitu: (a) kinerja sekolah, (b) kualitas kepemimpinan kepala sekolah, (c) supervisi, dan (d) partisipasi komite sekolah.

Kinerja sekolah adalah pencapaian atau prestasi sekolah yang dihasillkan melalui proses persekolahan (Slamet, 2003: 2). Kinerja sekolah dapat diukur dari kualitasnya, efektivitasnya, produktivitasnya, efisiensinya, inovasinya, kualitas kehidupan kerjanya, dan moral kerjanya (Depdiknas, 2001: 20). Dalam kaitannya dengan mutu output sekolah dapat dijelaskan bahwa prestasi sekolah dapat berupa prestasi akademik dan nonakademik Prestasi akademik berupa nilai ulangan umum, nilai ujian akhir sekolah, karya ilmiah dan sebagainya, sedangkan prestasi nonakademik dapat berupa kejujuran, kesopanan, olah raga, kesenian, ketrampilan, dan kegiatan-kegiatan ekstrakurikuler lainnya.

Dewasa ini output sekolah yang berkualitas sedang menjadi sorotan publik. Mutu output sekolah yang baik menjadi dambaan setiap orang. Beberapa faktor penting sebagai penentu mutu output sekolah antara lain kualitas kepemimpinan kepala sekolah, partisipasi komite sekolah, dan peran serta supervisinya. Bagaimana kualitas kepemimpinan kepala sekolah, partisipasi komite sekolah, dan peran serta supervisi akan menentukan mutu lukusannya. 
Burhanuddin (1994: 78) menegaskan bahwa: di bidang kekepalasekolahan, kualitas kepemimpinan yang penting dapat diklasifikasikan menjadi empat kategori pokok yang saling berhubungan dan inter-dependen, yaitu: (a) personality, (b) purposes, (c) knowledge, dan (d) professional skills. Personality kepala sekolah tercermin dalam sifat-sifat jujur, percaya diri, bertanggung jawab, berani mengambil resiko, berjiwa besar, kestabilan emosi, dan keteladanan. Purposes adalah tujuan yang ingin dicapai, yaitu berupa harapan-harapan masyarakat. Dengan demikian, tujuan sekolah merupakan cerminan dari harapan masyarakat, baik pada masa kini maupun masa mendatang yang selanjutnya disebut visi sekolah (Burnham, 1997: 118). Dalam konteks ini knowledge adalah pengetahuan yang relevan dengan bidang tugasnya. Pengetahuan kepala sekolah tercermin dalam kemampuan memahami kondisi tenaga kependidikan, memahami karak-teristik siswa, memahami program pengembangan tenaga kependidikan, dan memahami kritik dan saran. Professional skills dapat tercermin dalam kemampuan mengambil keputusan dan kemampuan berkomunikasi (Mulyasa, 2003: 115).

Dalam proses pembelajaran, supervisi merupakan bagian yang tidak terpisahkan dalam upaya meningkatkan prestasi belajar siswa. Sahertian (2000: 19) menegaskan bahwa supervisi tidak lain dari usaha memberikan layanan kepada guru-guru, baik secara individual maupun secara kelompok dalam usaha memperbaiki pengajaran. Burhanuddin (1990: 284) menegas-kan bahwa supervisi pendidikan pada hakikatnya merupakan segenap bantuan yang ditunjukan pada perbaikan-perbaikan dan pembinaan aspek pengajaran. Bantuan yang diberikan kepada guru harus berdasarkan penelitian atau pengamatan dan penilaian yang objektif dan mendalam sehingga bantuan yang diberikan tepat sasaran. Demikian pula bantuan yang diberikan harus mampu memperbaiki dan mengembangkan situasi belajar mengajar. Dengan demikian, aktivitas supervisi pembelajaran mencakup aspek penelitian, penilaian, perbaikan, dan pengembangan situasi pembelajaran.

Model manajemen berbasis sekolah menuntut adanya partisipasi yang tinggi dari warga sekolah dan warga masyarakat. Keterlibatan warga sekolah dan warga masyarakat ditampung dalam suatu wadah yang disebut komite 
sekolah. Oleh karena itu, komite sekolah merupakan salah satu partner sekolah dalam meningkatkan kinerja sekolah. Adapun peran komite sekolah dalam meningkatkan kinerja sekolah antara lain: (a) memberikan pertimbangan dalam penentuan dan pelaksanaan kebijakan pendidikan, (b) memberikan dukungan, baik yang bersifat finansial, pemikiran maupun tenaga dalam penyeleng-garaan pendidikan, (c) turut serta memberikan pengawasan dalam penyelenggaraan pendidikan, dan (d) sebagai mediator antara pemerintah dan masyarakat (Mulyasa, 2003: 190). Dengan demikian, partisipasi komite sekolah dalam penyelenggaraan pendidikan men-cakup tiga hal, yaitu: (a) keterlibatan dalan perencanaan pendidikan, (b) keterlibatan dan pelaksanaan pendidikan, serta (c) keterlibatan dalam evaluasi dan pengawasan terhadap penyelenggaraan pendidikan.

\section{Metode Penelitian}

Penelitian ini dilaksanakan di tingkat sekolah dasar yang berada di wilayah Cabang Dinas Pendidikan Kecamatan Grogol, Kabupaten Sukoharjo. Populasinya adalah seluruh guru kelas yang berdinas di sekolah dasar seKecamatan Grogol, Sukoharjo. Adapun teknik pengambilan sampel dilakukan dengan cluster random sampling. Populasi berjumlah 240 orang guru kelas. Sampel yang diambil berjumlah 150 orang guru kelas.

Aspek yang akan diungkap ada empat variabel yakni: (a) kualitas kepemimpinan kepala sekolah $\left(X_{1}\right)$, (b) aktivitas supervisi pembelajaran $\left(X_{2}\right)$, (c) partisipasi komite sekolah $\left(\mathrm{X}_{3}\right)$ dan (d) kinerja sekolah $(\mathrm{Y})$. Kinerja sekolah merupakan variabel terikat, sedangkan lainnya merupakan variabel bebas. Adapun hubungan variabel bebas dan variabel terikat dapat dilihat pada Gambar 1 berikut. 


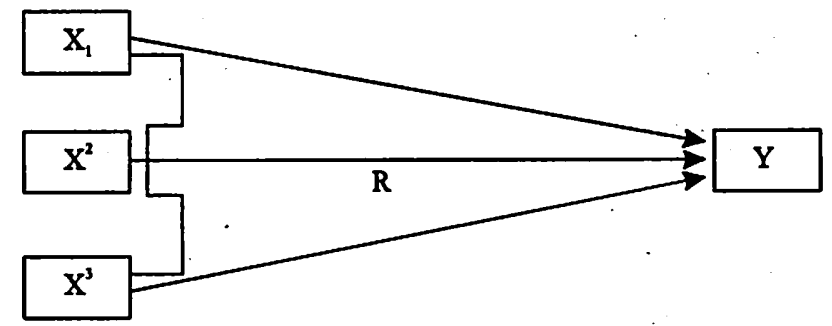

Gambar 1. Hubungan antara variabel bebas $\left(X_{1}, X_{2}, X_{3}\right)$ dengan variabel terikat $(\mathrm{Y})$.

Pengumpul data menggunakan angket, dan data yang telah terkumpul dianalisis dengan menggunakan analisis deskriptif dan regresi ganda. Analisis deskriptif dilakukan untuk memperoleh gambaran tentang tingkat kualitas kepemimpinan kepala sekolah, supervisi pembelajaran, partisipasi komite sekolah dan kinerja sekolah. Analisis deskriptif dilakukan dengan bantuan SPSS versi 10. Di samping itu, dilakukan pula analisis deskriptif dengan persentase. Analisis regresi ganda dilakukan dengan dengan bantuan SPSS versi 10. Analisis regresi ganda dimaksudkan untuk menguji hipotesis yang diajukan, yakni:

1. Ada pengaruh positif dan signifikan kualitas kepemimpinan kepala sekolah terhadap kinerja sekolah.

2. Ada pengaruh positif dan signifikan aktivitas supervisi pembelajaran terhadap kinerja sekolah.

3. Ada pengaruh positif dan signifikan partisipasi komite sekolah terhadap kinerja sekolah.

4. Ada pengaruh positif dan signifikan kualitas kepemimpinan kepala sekolah, supervisi, dan partisipasi komite sekolah terhadap kinerja sekolah.

\section{Hasil Penelitian dan Pembahasan}

Hasil penelitian disajikan dalam dua kelompok yaitu hasil analisis deskriptif dan hasil analisis regresi ganda. Hasil analisis deskriptif menunjukan bahwa: 
1. Kualitas kepemimpinan kepala sekolah dalam kategori sedang (rerata = 78,08), adapun tingkat persentase kualitas kepemimpinan kepala sekolah sebesar $75 \%$ dari kriteria yang ditetapkan.

2. Aktivitas supervisi pembelajaran dalam kategori sedang (rerata $=72,79$ ), adapun tingkat persentase aktivitasnya sebesar $67 \%$ dari kriteria yang ditetapkan.

3. Partisipasi komite sekolah dalam kategori sedang (rerata $=39,45$ ), adapun tingkat persentase partisipasinya sebesar $66 \%$ dari kriteria yang ditetapkan.

4. Kinerja sekolah dalam kategori sedang (rerata $=31,14$ ), dengan tingkat persentase kinerja sebesar $65 \%$ dari kriteria yang ditetapkan.

Analisis regresi ganda dilakukan untuk menguji hipotesis yang diajukan.

Adapun hasil analisis menunjukan bahwa:

1. Terdapat pengaruh positif dan signifikan kualitas kepemimpinan kepala sekolah terhadap kinerja sekolah dengan r sebesar 0,543; $p<0,05$ dan kualitas kepemimpinan kepala sekolah memberikan sumbangan efektif sebesar $29,5 \%$.

2. Terdapat pengaruh positif dan signifikan aktivitas supervisi pem-belajaran terhadap kinerja sekolah dengan $r$ sebesar 0,$472 ; p<0,05$ dan supervisi pembelajaran memberikan sumbangan efektif sebesar $8,6 \%$.

3. Terdapat pengaruh positif dan signifikan partisipasi komite sekolah terhadap kinerja sekolah dengan $\mathrm{r}$ sebesar 0,$506 ; \mathrm{p}<0,05$ dan partisipasi komite sekolah memberikan sumbangan efektif sebesar $5 \%$.

4. Terdapat pengaruh positif dan signifikan antara kualitas kepemimpinan kepala sekolah, supervisi dan partisipasi komite sekolah terhadap kinerja sekolah dengan $\mathrm{R}$ sebesar $0,656 \mathrm{df}=3: 146 ; \mathrm{p}<0,05$. Adapun tingkat diterminasinya sebesar $43,1 \%$.

Secara umum kualitas kepemimpinan kepala sekolah di tingkat sekolah dasar di wilayah Cabang Dinas Pendidikan Kecamatan Grogol Kabupaten Sukoharjo dalam kategori sedang, dengan tingkat persentase kualitas kepemimpinannya sebesar $75 \%$. Hal ini menunjukkan bahwa kualitas kepemimpinan kepala sekolah belum maksimal. Belum mak-simalnya kepemimpinan kepala sekolah ini tentu banyak faktor yang mempengaruhinya. 
Jika dilihat dari aspek-aspeknya, kualitas kepemimpin-an kepala sekolah mencakup empat aspek, yakni aspek: visi dan misi, kepribadian, pengetahuan, dan skill. Keempat aspek ini yang paling lemah adalah aspek skill (67\%), kemudian disusul oleh aspek visi dan misi (69\%), aspek pengetahuan (78\%), dan aspek kepribadian (84\%). Tingkat persentase tersebut dapat dimaknai bahwa belum maksimalnya kualitas kepemimpinan kepala sekolah karena dukungan skill dari para kepala sekolah masih sangat rendah.

Aktivitas supervisi pembelajaran di tingkat sekolah dasar di wilayah Cabang Dinas Pendidikan Kecamatan Grogol, Kabupaten Sukoharjo dalam kategori sedang, dan tingkat persentase aktivitasnya mencapai $67 \%$. Aktivitas supervisi pembelajaran ini terdiri dari empat aspek yakni: meneliti $69 \%$, menilai $71 \%$, memperbaiki $74 \%$, dan mengembangkan $57 \%$. Dari keempat aspek ini ternyata aspek pengembangan berada pada posisi yang paling rendah. Angkaangka tersebut menggamabarkan bahwa aktivitas supervisi pembelajaran di wilayan tersebut masih belum maksimal. Hal ini terjadi karena belum terjadi perubahan yang berarti dalam hal sikap, pola pikir, dan perilaku dari supervisor sesuai dengan model manajeman yang berlaku.

Partisipasi komite sekolah pada tingkat sekolah dasar di wilayah Cabang Dinas Pendidikan Kecamatan Grogol, Kabupaten Sukoharjo berada dalam kategori sedang dengan tingkat partisipasi sebesar $66 \%$. Angka ini menunjukkan bahwa partisipasi komite sekolah masih jauh dari harapan. Jika dilihat dari tingkat persentase partisipasi tiap-tiap aspek, partisipasi dalam aspek perencanaan sebesar $72 \%$, aspek pelaksanaan $62 \%$ dan aspek evaluasi dan pengawasan sebesar 61\%. Angka tersebut dapat dimaknai bahwa partisipasi komite sekolah baru pada tataran perencanaan, seperti misalnya keterlibatan dalam membuat RAPBS, sedangkan dukungan nyata pada aspek penyelenggaraan dan pengawasan pendidikan masih jauh dari harapan.

Kinerja sekolah dasar di wilayah Cabang Dinas Pendidikan Kecamatan Grogol, Kabupaten Sukoharjo berada dalam kategori sedang dengan tingkat persentase kinerja sebesar $65 \%$. Keadaan ini dapat dimaknai bahwa kualitas proses dan input di sekolah-sekolah tersebut masih jauh dari harapan. Dengan kata lain, kualitas kepemimpinan, manajemen, dan pembelajarannya masih 
belum maksimal. Hal ini terjadi karena kualitas sumber daya manusia dan sumber daya lainnya masih jauh dari kualitas yang diharapkan.

Dalam pengujian hipotesis diperoleh kesimpulan bahwa kualitas kepemimpinan kepala sekolah, supervisi pembelajaran, dan partisipasi komite sekolah berpengaruh positif dan signifikan terhadap kinerja sekolah. Sumbangan efektif kualitas kepemimpinan kepala sekolah terhadap kinerja sekolah sebesar 29,5\%; sumbangan efektif supervisi pembelajaran terhadap kinerja sekolah sebesar 8,6\%; dan sumbangan efektif partisipasi komite sekolah terhadap kinerja sekolah sebesar 5\%. Hal ini dapat dimaknai bahwa meskipun kualitas kepemimpinan kepala sekolah, supervisi, dan partisipasi komite sekolah berpengaruh positif dan signifikan terhadap kinerja sekolah, namun masih dalam tataran yang belum maksimal. Di samping itu, kontribusinya belum seimbang. Ketidak-seimbangan dalam kontribusi ini dapat mengakibatkan timbulnya kesulitan dalam mengelola pendidikan yang pada gilirannya menghambat usaha-usaha peningkatan mutu output pendidikan.

\section{Simpulan}

Berdasarkan hasil penelitian dan pembahasan di atas, maka diperoleh kesimpulan sebagai betikut. Kualitas kepemimimpinan kepala sekolah, supervisi, partisipasi komite sekolah dan kinerja sekolah di sekolah dasar di wilayah Cabang Dinas Pendidikan Kecamatan Grogol, Kabupaten Sukoharjo dalam kategori sedang. Kualitas kepemimpinan kepala sekolah, supervisi pembelajaran dan partisipasi komite sekolah berpengaruh positif dan signifikan terhadap kinerja sekolah. Meskipun demikian, kontribisi dalam meningkatkan kinerja sekolah masih belum maksimal.

\section{Saran-saran}

Perlu adanya pembaharuan tentang tata cara perekrutan dan persyaratan sebagai kepala sekolah. Pembaharuan yang dimaksud adalah pembaharuan yang sesuai dengan tuntutan perubahan. Dengan model manajeman berbasis sekolah, tata cara perekrutan kepala sekolah lebih memperhatikan kemampuan kompetensi, skill, karakteristik, dan visi calon kepala sekolah itu sendiri. 
Sebaiknya kepala sekolah dipilih secara demo-kratis dengan tidak terpaku pada kepangkatan calon tersebut.

Perlu adanya perubahan sikap, pola pikir dan pola tindak dari petugas. supervisi. Perubahan yang dimaksud adalah perubahan yang disesuaikan dengan paradigma manajemen dan kepemimpinan yang berlaku. Model manajemen berbasis sekolah lebih menempatkan supervisi sebagai pembina, penasihat, konsultan bagi sekolah-sekolah yang menjadi tanggung jawabnya. Dengan kata lain, fungsi supervisi di sekolah disesuaikan dengan kondisi dan situasi sekolah serta masyarakatnya.

Perlu adanya sosialisasi komite sekolah yang lebih intensif, sehingga mampu membangun kesadaran warga sekolah dan warga masyarakat dalam meningkatkan mutu pendidikan. Pemahaman akan fungsi dan peran komite sekolah dimugkinkan dapat membantu meningkatkan kesadaran dari semua pihak yang berkepentingan terhadap pendidikan, yang pada gilirannya akan mampu meningkatkan partisipasi dalam meningkatkan mutu pendidikan.

\section{Daftar Pustaka}

Burhanuddin. (1990). Analisis administrasi manajemen dan kepemimpinan pendidikan. Jakarta: Bumi Aksara.

Departemen Pendidikan Nasional. (2001). Manajemen peningkatan mutu berbasis sekolah, buku 1-3. Jakarta: Direktorat Jendral Pendidikan Dasar dan Menengah.

Departemen Pendidikan Nasioanl. (2002). Undang-Undang Republik Indonesia. Nomor 20 tabun 2003, tentang Sistem Pendidikan Nasional. Jakarta: Direktorat Jendral Pendidikan dasar dan menengah.

Mulyasa, E. (2003). Manajemen berbasis sekolab. Bandung: Remaja Rosdakarya. Saherian, P.A. (2000). Konsep dasar \& teknik supervisi pendidikan. Jakarta: Bineka Cipta.

Sahertian, P.A. \& Mataheru, F. (1982). Prinsip dan teknik supervisi pendidikan. Surabaya: Usaha Nasional.

Slamet, P. H. (2003). Karakteristik kepala sekolab tanggub. Diambil pada tanggal 25 Nopember 2004, dari http/www.pdk.id/jurnal/25/ slametph.htm. 